\title{
PHYSICAL-HYDRIC DYNAMICS OF A PEDOLOGICAL LATOSOL-NITOSOL SYSTEM
}

(a) Phd in Geography, Federal Technological University of Paraná (UTFPR). http://lattes.cnpq.br/1212375854250124

(b) Phd in Geography, State University of West Paraná (UNIOESTE). http://lattes.cnpq.br/9964163479344142

(c) Phd in Geoscience, State University of Maringá (UEM). http://lattes.cnpq.br/7208438239950541

\section{(*) CORRESPONDING AUTHOR}

Address:-Avenida Brasil, nº 4232. CEP: 85884-000, Medianeira (PR), Brasil. Tel: (+55 45) 32408000

E-mail: vlmagalhaes@utfpr.edu.br

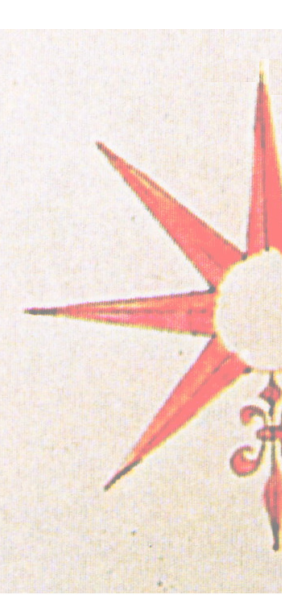

\begin{abstract}
In order to comprehend the hydric dynamics of soils along the slopes, the research took place on a slope from Marechal Cândido Rondon, Paraná. Trenches were open to the macromorphological description, sample collection for physical, chemical and micromorphological analysis and quantification of hydraulic conductivity. In the top sector, Eutroferric Red Latosol was identified, and from the middle sector, the latosolic Distroferric Red Nitosol predominates. In micromorphological terms, the Ap and Bw horizons have presented two distinct types of arrangements: a continuous and/or discontinuous porphyric fabric with cavities and planar pores and other with enaulic fabric, with high connectivity - compound packing porosity. In the AB and nitic B horizons the enaulic fabric is less representative, prevailing the continuous porphyric fabrics, which make the pores less communicating. The Ap and Bw horizons have shown higher hydraulic conductivity, while $\mathrm{AB}$ and $\mathrm{B}$ nitic horizons had the lowest rates, reinforcing the notion that besides soil density, the pores arrangement directly interfereswith the hydric behavior of the pedological system.
\end{abstract}

Keywords: Nitic horizon; Latosolic B horizon; Micromorphology; Hydraulic conductivity.

\section{RESUMO/RESUMEN}

\section{DINÂMICA FÍSICO-HÍDRICA DE UM SISTEMA PEDOLÓGICO LATOSSOLO-NITOSSOLO}

Com o objetivo de compreender a dinâmica hídrica dos solos, realizou-se esta pesquisa em uma vertente, do platô da cidade de Marechal Cândido Rondon, Paraná. Foram abertas trincheiras para a descrição macromorfológica, coleta de amostras para as análises físicas, químicas, micromorfológicas e quantificação da condutividade hidráulica. No setor de topo, foi identificado o Latossolo Vermelho Eutroférrico e a partir da média baixa vertente, o Nitossolo Vermelho Distroférrico latossólico. Em termos micromorfológicos, os horizontes Ap e Bw apresentam dois tipos de arranjos distintos: um de trama enáulica, com alta conectividade - porosidade de empacotamento composto, e outro de trama porfírica contínua e/ou descontínua, com cavidades e os poros planares. Nos horizontes AB e B nítico a trama enáulica é menos representativa, predominando a trama porfírica contínua, que deixa os poros menos comunicantes. Em termos hídricos, os horizontes Ap e Bw indicaram maior condutividade hidráulica, enquanto o $\mathrm{AB}$ e $\mathrm{B}$ nítico apresentaram os menores índices, reforçando que além da densidade do solo, o arranjo dos poros interfere diretamente no comportamento hídrico do sistema pedológico.

Palavras-chave: B nítico; B latossólico; Micromorfologia; Condutividade hidráulica.

\section{DINÁMICA FÍSICO-HÍDRICA DE UN SISTEMA PEDOLÓGICO LATOSOL-NITOSOL}

Con el objetivo de comprender la dinámica hídrica de los suelos, se realizó investigación en una vertiente de la meseta de la ciudad de Marechal Cândido Rondon, Paraná. Se abrieron zanjas para la descripción macromorfológica, colecta de muestras para los análisis físicos, químicos, micromorfológicos y la cuantificación de la conductividad hidráulica. En el sector superior, fueron mapeados el Latosol Rojo Eutroférrico y a partir de la media y baja vertiente, el Nitosol Rojo Distroférrico latosólico. En los análisis micromorfológicos, los horizontes Ap y Bw presentan dos tipos de disposiciones distintas: una de trama enáulica, con poros inter- agregados con alta conectividad - porosidad de envoltorio compuesto, y otra de trama porfídica continua y descontinua, con cavidades y poros planeares. En los horizontes AB y B nítico la trama enáulica es menos representativa, predominando la trama porfídica continua, que deja los poros menos comunicantes. En términos hídricos, los horizontes Ap e Bw indicaron mayor conductividad hidráulica, mientras que el $\mathrm{AB}$ y $\mathrm{B}$ nítico presentaron los menores índices, reforzando que además de la densidad del suelo, la disposición de los poros interfiere en el comportamiento hídrico del sistema pedológico.

Palabras clave: B nítico; B latosólico; Micromorfología; Conductividad hidráulica- 


\section{INTRODUCTION}

Integrated landscape study, especially its characteristics and operation, have presented themselves as vital for both rural and urban land-use planning. According to Ruellan and Dosso (1993), is necessary for understanding the landscape from macro to micro-scale. The knowledge of the pedological cover contributes, in this sense, to identify the arrangement of soil in the landscape in a bi-dimensional and tri-dimensional way, as a pedological continuum, since they undergo different actions and reactions in space and time.

The soil is a dynamic portion of the landscape, from a tri-dimensional nature that synthesizes, in its profile, many influences of the present and past. For Ruellan (1988) there is a need to comprehend the soil as an organized, structured, living medium, with its own dynamics even before its effective utilization. Such approach is deemed necessary since the man-made use and management of this natural element changes not only its structure but mainly its functioning, and according to the author, it causes widespread changes in other characteristics of the environment, be it natural (terrain, climate, vegetation) and/or anthropic (use and management methods).

Soil or pedological surveying generates information that allows the classification, monitoring, and evaluation of agricultural aptness, project productivity and establishes the best manner for land use. Such combined pieces of information can be organized in zoning maps as an essential part of regional agricultural planning for both rural and urban rural properties. There are a great number of projects that require spatial soil information in terms of surface and different depths, contributing along with the knowledge of spatial soil distribution in more detailed scales.

There is a consensus that land use for agriculture entails changes in its natural characteristics. Agricultural soils have been seeing great modifications, where soil compaction is identified as the main cause for such changes, due to the traffic of tractors and agricultural machines being inadequately used (RAPER, 2005). The changes caused by the physical properties are one of the first that appear, varying in their intensity according to the cultivation system used. The modifications occur mainly in the structure, affecting density, porosity, and aeration, causing changes in water flow and retention of that system (CARDOSO et al., 2006).

Water, sediments, and chemical elements transference on slope sectors occur via several flows that vary in space and time, in a superficial and sub superficial manner, resulting in differentiations and discontinuing of processes, not only in slope sectors forms but also in soil categories arranged on each topographic segment.

In order to comprehend the dynamics of water on soil, it is necessary to recognize some of its morphological characteristics, such as texture and structure, responsible for the organization of the porous system. According to Bertoni and Lombardi Neto (2005), it is the size and arrangement of porous spaces that directly influence water infiltration speed in soil. These movements are carried out by gravitational and capillarity forces. Gravitational force promotes water movement of large pores in saturated soils, whereas the capillarity force occurs on non-saturated soils (REICHARDT, 1990).

Reichardt (1990) defines the hydraulic conductivity as volume water that passes through, by time unit, a specific soil area driven by a difference in potential. It is concluded that conductivity coefficient expresses the facility for a fluid such as water to be transported through a porous medium such as soil, dependable both from the soil and water properties. Among soil properties, the following characteristics can be highlighted; size distribution and particles form, specific surface, and porosity, in other words, all properties that are reflected on the porous geometry of the soil.

Mesquita and Moraes (2004) corroborate that the saturated hydraulic conductivity of a soil is determined by the geometry and pores taken by water, therefore becoming dependent on shape, quantity, distribution, and above all, their continuity.

Thereby, studies about hydric behavior of pedological covers, aiming at understanding their morpho-pedological transformations on slope sector (toposequence) and on landscape (hydrographic basin), must prioritize the use of techniques that allow the distribution and redistribution evaluation 
of matters (silts and clays) on different topographic segments of slope sectors, such as micromorphology, highlighted by Castro (1989), Ruellan and Dosso (1993), Kertzman (1996), Castro et al. (2003), and Filizola and Gomes (2006).

According to Filizola and Gomes (2006), micromorphology corresponds to a scale of pedological cover observation, crucial for the understanding of its organization and functioning. The adequate use of micromorphology involves detailed information of the distribution of pedological horizons, both on the profile and on the landscape. Therefore, micromorphological observation is considered a zoom in into the pedological cover organization.

Micromorphology technique is considered efficient either on soil genesis and dynamics or on evaluation and monitoring of various agricultural practices. Micromorphology is capable of giving porosity and permeability results with precision (in two dimensions) with the aid of processing and digital image analysis techniques, as well as allowing the visualization of structural alterations caused by densification and compaction in accordance with Castro (1989), Ruellan and Dosso (1993), Kertzman (1996), Castro et al. (2003), and Filizola and Gomes (2006).

There is a consensus among researchers (DERPSCH et al., 1990; De MARIA et al., 1999; TAVARES FILHO et al., 2006) that different soil management systems have the purpose to create favorable conditions for the development of crops. However, a disregard for more favorable conditions for soil preparation and the use of larger and heavier machinery for that could cause structural modifications to the soil. That could cause either greater or lesser soil compaction interfering on soil density, porosity, water infiltration in the soil, and on the root development of crops, consequently reducing their productivity. It is also highlighted that studies of such nature could contribute towards the knowledge of physical-chemical, physical-hydrological, and micromorphological attributes, emphasizing the genesis and evolution of soils. Such studies are made evident, either separately or simultaneously, in works from Vidal-Torrado et al. (2005), Cunha et al. (2008), and Tavares Filho and Tessier (2010).

Learning about the porous arrangement and hydraulic conductivity of the soils on the slope sectors is crucial to establishing water flow on soils, and from a practical viewpoint, for the creation of irrigation and draining projects, as well as for quantification of chemical substances leaching and erosion.

Therefore, this studies aims at presenting the physical-hydric behaviour and micromorphological aspects of a Latosol/Nitosol pedological system in Marechal Cândido Rondon, West of Paraná state, Brazil, an agriculture-based economy.

\section{MATERIALS AND METHODS}

The municipality of Marechal Cândido Rondon is located on the far west of Paraná state, between parallels of latitude $24^{\circ} 26^{\prime}$ and $24^{\circ} 46^{\prime}$ 'South and longitude $53^{\circ} 57^{\prime}$ e $54^{\circ} 20^{\prime}$ West (Figure 1). It shows in its 748-sq.km area sectors of three morpho-sculptural sub-units of Third Paraná Plateau, on Paraná Sedimentary Basin: Cascavel Plateau, São Francisco Plateau, and Foz do Iguaçu Plateau (MINEROPAR, 2006).

The Cascavel Plateau morpho-sculptural sub-unit stretches through the North-eastern sector of the municipality, where the urban plot of Marechal Cândido Rondon is located, locally identified as a landscape unit - Plateau de Marechal - by Moresco (2007). On this plateau, there is a dominance of medium dissection terrain, characterized by hills with elongated and flattened summits, convex slopes with declivities, in general, lower than $12 \%$ and V- shaped valleys.

The Cascavel Plateau ends making way to a border zone carved by direct tributaries to Paraná and São Francisco rivers, which shape slopes with varied and pronounced declivities, quite often presenting steep segments on the summits and deep valleys. This carved border zone corresponds to the west side of the great interfluve, named Sao Francisco Plateau morpho-sculptural sub-unit. 
The western sector, characterized by wide low hills with long slopes and weak declivities, corresponds to Foz do Iguaçu Plateau.

The landscape unit Marechal Plateau (MORESCO, 2007), where the current research was done, is located on the North-eastern sector of the municipality, between 360 and $460 \mathrm{~m}$ altimetry quotas. The more elevated spurs keep the axis SE-NO and N-S. It is characterized by convex-straight slopes and $\mathrm{V}$-shaped narrow valleys, with gradient ruptures on the peak to high slope passage and steep declivity ( 8 to $20 \%$ ).

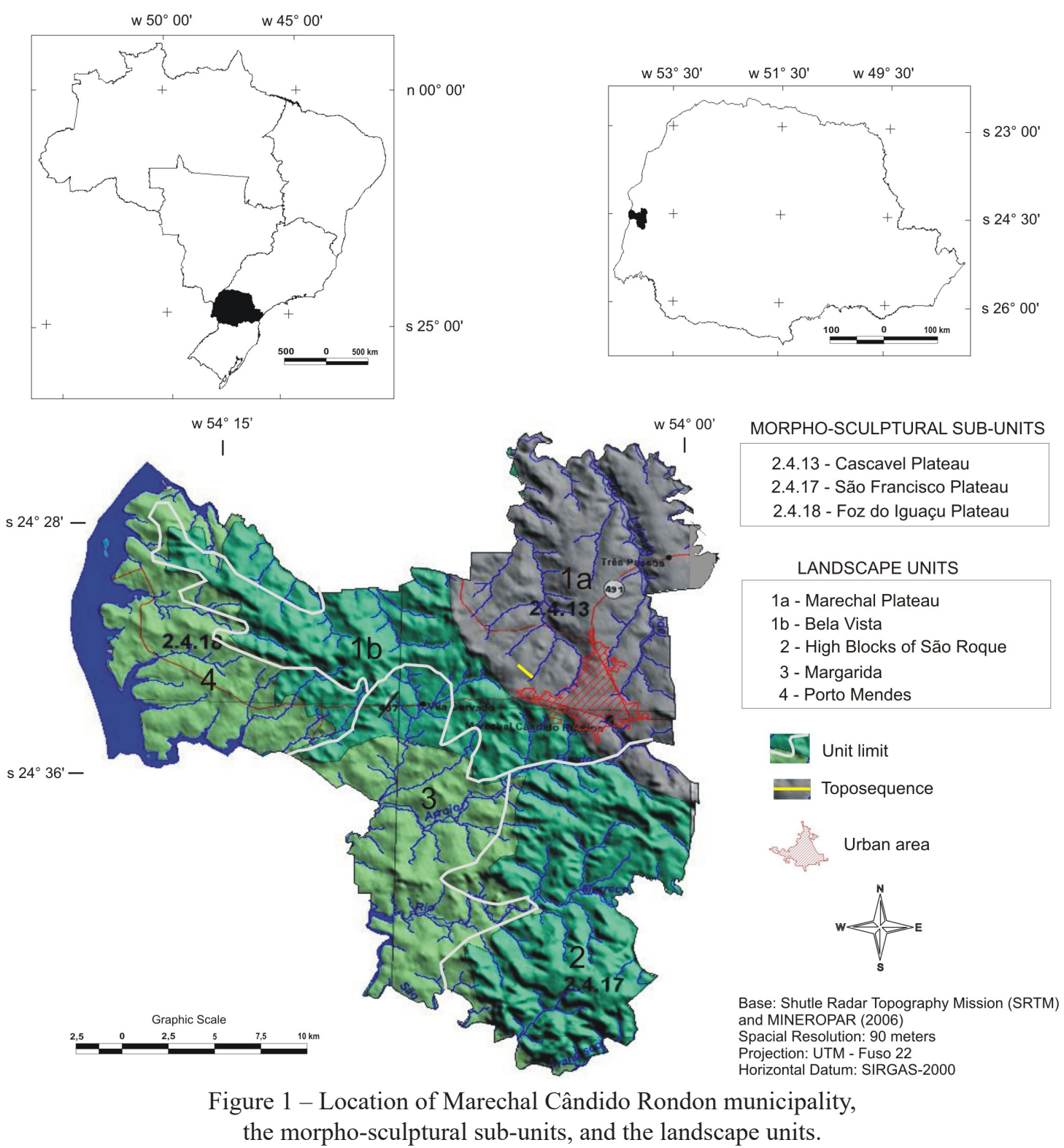

In order to obtain the knowledge of the pedological cover on the Marechal Plateau systemic surveys were done along the slope, followed by the opening of two trenches, respectively on the top and medium low slope sectors for the macro-morphological description (SANTOS et al., 2015), sample collection for physical, chemical, and micro-morphological analyses, as well as tests for hydraulic conductivity quantification (constant load permeameter) and macro and microporosity. It is worth highlighting that since the valley floor area (covered by woods) is altered and coated by sediment material, it was not possible to carry out the investigation on the lower segment of the slope.

The chemical analyses followed the Agronomic Institute of Paraná (IAPAR) technique (PAVAN et al.,) in the laboratory. The phosphor was established by spectrophotometry $(\kappa=360 \mathrm{~nm})$ and 
potassium by flame photometry. Interchangeable acidity (Al) determination was done in $\mathrm{KCl}$, and potential acidity $(\mathrm{H}+\mathrm{Al}$ ) with SMP buffer solution added to the sample used on the $\mathrm{pH}$ in $\mathrm{CaCl}$, with new $\mathrm{pH}$ reading with a potentiometer. $\mathrm{Ca} 2+$ and $\mathrm{Mg} 2+$ determinations were done by atomic absorption spectrophotometry (AAS), utilizing $\mathrm{Ca} 2+$ and $\mathrm{Mg} 2+$ standard solutions containing $\mathrm{La}$ and $\mathrm{KCl}$ at the same extract concentrations. The organic carbon was obtained using the Walkley-Black method with organic matter oxidation by $\mathrm{K} 2 \mathrm{Cr} 2 \mathrm{O} 7 \mathrm{1N}$ potassium dichromate in acid medium. The soil $\mathrm{pH}$ was established in $\mathrm{CaCl} 2$ and $\mathrm{H} 2 \mathrm{O}$ solution, under calibrated potentiometer with buffer solutions at $\mathrm{pH} 7.0$ and 4.0.

Soil granulometric fractions and clay dispersed in water were determined by the Bouyoucos densimeter method (EMBRAPA, 1997), both in triplicate. The determination of soil and porosity densities (macro and micro) followed the one proposed by Embrapa (1997), utilizing the mean of three soil samples collected in $147 \mathrm{~cm} 3$ stainless-steel volumetric rings on the diagnostic horizons. The hydraulic conductivity test established in these volumetric rings was done in the laboratory using constant load permeameter in three samples for each horizon, 8 readings totaling $8 \mathrm{~h}$. For the hydraulic conductivity calculation the mean of the last three readings was used, applying the following formula:

$$
\text { Ko }=\text { Q. L / A. H. t }
$$

Where:

$\mathrm{Ko}=$ hydraulic conductivity of saturated soil in $\mathrm{mm} / \mathrm{h}$;

$\mathrm{Q}=$ water volume in $\mathrm{mL}$ percolated on the sample;

$\mathrm{L}=$ length (height) of sample in $\mathrm{cm}$;

$\mathrm{H}=$ soil block and water column height;

$\mathrm{A}=$ soil cylinder area in $\mathrm{cm} 2$;

$\mathrm{t}=$ time in hours.

For results interpretation the following classes were employed according to Embrapa (1997) guidelines: very slow $(<1)$; slow (1-5), moderately slow (5-20), moderate (20-60), moderately fast (60-125), fast (125-250), and very fast $(>250)$.

The hydric dynamics study was done by micromorphological observation on thin sections obtained from non-deformed soil samples, collected in plastic containers measuring $6 \times 10 \times 5 \mathrm{~cm}$, dried in greenhouse at $380 \mathrm{C}$. The samples in dried state were impregnated with polyester resin, selecting thin slices between 2 and $4 \mathrm{~mm}$ in thickness, followed by the polishing of one of the sides using a polisher and assembling in a glass slide. After assembling, thinning was carried out until reaching 25 micrometers of thickness (CASTRO et al., 2003).

The thin sections observations were done with a petrography-type optical microscope, with 2.5 and $4 \mathrm{X}$ lenses, under natural light and crossed nicols (polarized light). Bullock et al. (1985) recommendations were followed on this stage for identification and classification of attributes and the soil components organizing (thin section) called micromass $(<2 \mu \mathrm{m})$, coarse material (from 2 to $2.000 \mu \mathrm{m}$ diameter), and pores (from 30 to $500 \mu \mathrm{m}$ ).

The images obtained with the optical microscope were subjected to ArcGIS ${ }^{\circledR} 10.1$ image classification software, in order to generate images showing pores geometry, shape, and connexion.

\section{RESULTS AND DISCUSSION}

\section{PHYSICAL AND CHEMICAL ATTRIBUTES}

The toposequence of Marechal Plateau is located in one of the drainage riverbeds of the canals that conjoin with the Guavirá stream, the main water course of the urban site. This toposequence is 
$790 \mathrm{~m}$ long and it has $45 \mathrm{~m}$ of uneven topography dominated by convex shape (Figure 2). Temporary crops with direct planting system for over 20 years are found along its entire extension.

Due to the prevalence of basaltic rocks (BHERING et al., 2007), the pedological cover is quite clayey along the whole toposequence (Table 1), presenting variations in color and structure. For this same research field, Magalhães et al. (2015) presented such macromorphological characteristics in detail, which indicates Ap horizon with a weak structure, made of small granules of $1 \mathrm{~cm}$ in diameter. $\mathrm{AB}$ horizon presents, due to the degree of compaction, the large subangular blocky structure of up to $5 \mathrm{~cm}$ in diameter, with strong levels of development. Such greater resistance of material could be due to compaction noted on the field and also by the soil density determined in the laboratory. Bw horizons showed that subangular blocky structures of up to $3 \mathrm{~cm}$ in diameter have moderate resistance, whereas B nitic of strong to the moderate structure is characterized by large subangular blocky structures of up to $5 \mathrm{~cm}$ in diameter. The presence of strong clay films was evidenced mainly on the walls of the blocks. Small variations of color were highlighted, for instance, dark-reddish-brown (2.5YR 3/4) on the surface and greyish-dark-red (10R 3/4) on Bw and B nitic.

Based on the variation of these morphological characteristics, along with the $320 \mathrm{~m}$ extension from the summit to the medium slopes (surveys 3 to 6 and trench 2), Ap, AB, Bw1, and Bw2 horizons were identified. On the remaining $470 \mathrm{~m}$ of extension from the medium slope to the valley bottom (surveys 2 to 6 and trench 2), Ap, AB, B nitic, and Bw horizons were identified.

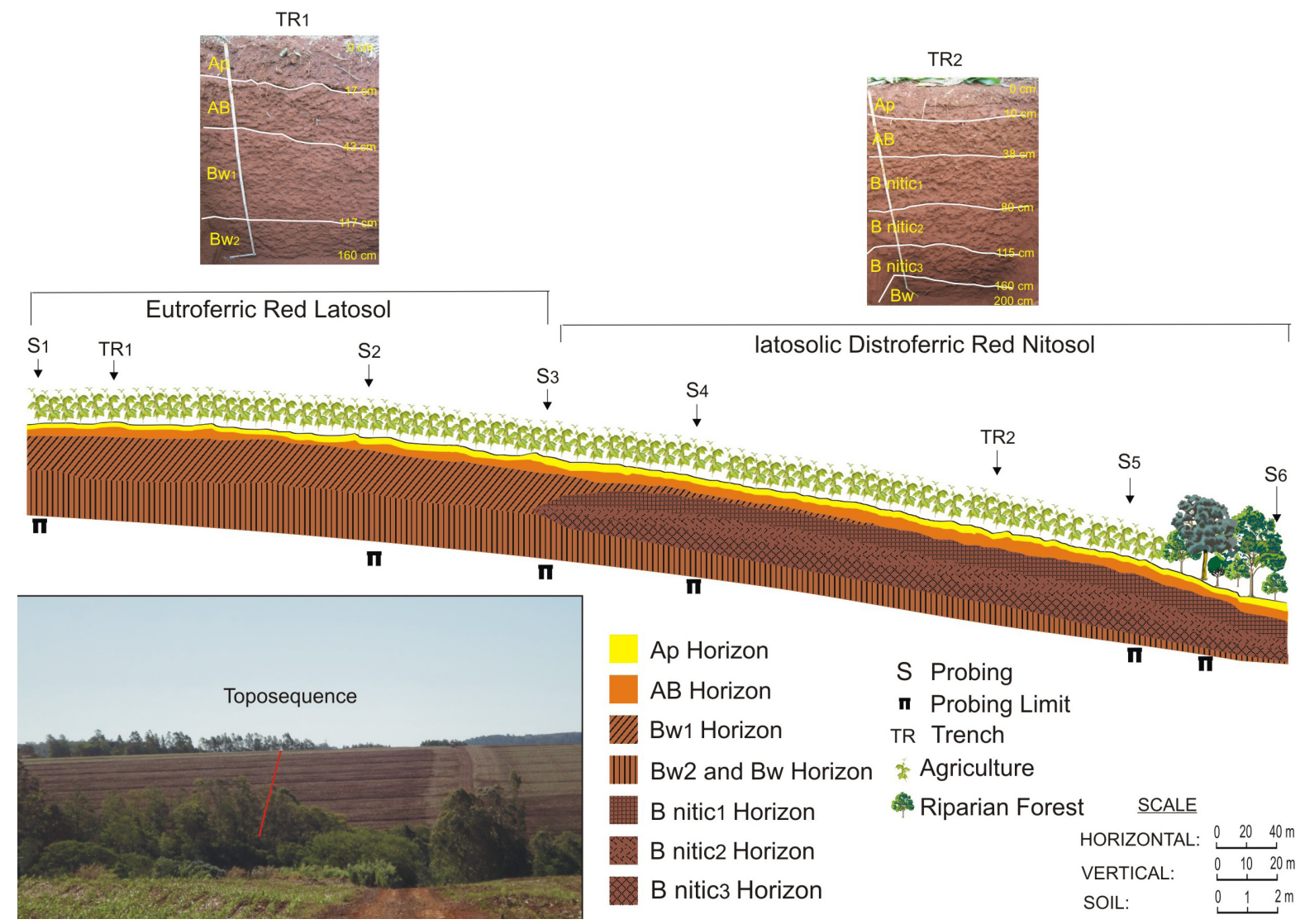

Figure 2 - Toposequence of soils from Marechal Plateau.

Such sequence of horizons and their morphological characteristics allow classification this pedological system as Red Latosol / Red Nitosol and, also, taking into account that it is basalt rock creating soils with high levels of iron oxide $(>18 \%)$ it is identified with ferric quality, as done by Bhering et al. (2007), when updating the soil map of Paraná state.

Flocculation, as well as dispersion levels, presented a $64 \%$ range on the diagnosed horizons. On the summit sector, Ap and AB horizons presented $32 \%$ and $48 \%$ of flocculation, respectively. While on the medium slope, Ap horizon keeps values close to the summed ones, AB volume presented $96 \%$ flocculation, demonstrating a $50 \%$ increase laterally on the slope. 
Bw sub surface horizon on slope summit showed more flocculated clay than on the surface, presenting values around $81 \%$, which decreases laterally to $78 \%$. B nitic volumes were more flocculated in terms of depth, initiating with $78 \%$ on B1 nitic and reaching $96 \%$ on B3 nitic. It can be determined in this case, that agricultural practices (use of organic manure) are interfering and increasing the values of clay dispersed on the surface, just as diagnosed by Barbosa et al. (2015) on Red Latosols from the North of Paraná state.

Table 1 - Physical characteristics of soil profiles from Marechal Plateau toposequence.

\begin{tabular}{|c|c|c|c|c|c|c|c|c|c|}
\hline \multirow{3}{*}{$\begin{array}{l}\text { Trench } \\
\text { Horizon }\end{array}$} & \multirow{3}{*}{$\begin{array}{l}\text { Horizon } \\
\text { Depth } \\
\text { (cm) }\end{array}$} & \multicolumn{3}{|c|}{ Granulometry } & \multirow{3}{*}{$\begin{array}{l}\text { Natural } \\
\text { Clay }\end{array}$} & \multirow{3}{*}{$\begin{array}{l}\text { Degree of } \\
\text { Floccula- } \\
\text { tion }\end{array}$} & \multirow{3}{*}{$\begin{array}{l}\text { Degree of } \\
\text { Dispersion }\end{array}$} & \multirow{3}{*}{$\begin{array}{l}\text { Particle } \\
\text { Density } \\
\mathrm{g} \mathrm{cm}^{-3}\end{array}$} & \multirow{3}{*}{$\begin{array}{l}\text { Rela- } \\
\text { tionship } \\
\text { silt / clay }\end{array}$} \\
\hline & & & $\%$ & & & & & & \\
\hline & & Clay & Silt & Sand & & & & & \\
\hline 1- Ap & $00-17$ & 73.08 & 16.38 & 10.54 & 49.72 & 32 & 68 & 2.72 & 0.2 \\
\hline $1-\mathrm{AB}$ & $17-43$ & 83.08 & 9.54 & 7.38 & 43.08 & 48 & 52 & 2.73 & 0.1 \\
\hline 1- Bw1 & $43-117$ & 76.40 & 16.90 & 6.7 & 14.74 & 81 & 19 & 2.77 & 0.2 \\
\hline 1- Bw2 & $117-160+$ & 79.72 & 13.38 & 6.9 & 14.74 & 82 & 18 & 2.77 & 0.2 \\
\hline 2- Ap & $00-10$ & 79.36 & 8.62 & 12.02 & 51.38 & 35 & 65 & 2.75 & 0.1 \\
\hline $2-\mathrm{AB}$ & $10-38$ & 81.02 & 7.14 & 11.84 & 3.08 & 96 & 4 & 2.70 & 0.1 \\
\hline 2- B nitic 1 & $38-80$ & 82.72 & 8.60 & 8.68 & 18.08 & 78 & 22 & 2.74 & 0.1 \\
\hline 2- B nitic 2 & $80-115$ & 86.04 & 5.54 & 8.42 & 13.08 & 85 & 15 & 2.75 & 0.1 \\
\hline 2- B nitic 3 & $115-160$ & 86.40 & 5.16 & 8.44 & 3.08 & 96 & 4 & 2.80 & 0.1 \\
\hline $2-\mathrm{Bw}$ & $160-200+$ & 86.40 & 5.72 & 7.88 & 19.36 & 78 & 22 & 2.80 & 0.1 \\
\hline
\end{tabular}

According to Embrapa (1984), Latosols have a high flocculation level on Bw horizon that could reach $100 \%$. Such contribution also occurs due to the degree of weathering that increase flocculation levels on tropical soils. The basic division of silt by clay contents, summarizing the relation silt/clay, generated values between 0.1 and 0.2 , confirming the high evolution levels of soils from this toposequence. Silva and Castro (2015) after analyzing a clayey Distroferric Red Latosol of sugarcane cultivation in the state of Goiás, Brazil, noted that the flocculation level on most of the horizons reached $100 \%$, and none of them were lower than $80 \%$, reinforcing a typical condition of this type of soil.

In terms of chemical properties of these soils (Table 2), the $\mathrm{pH}$ values in $\mathrm{H} 2 \mathrm{O}$ are always superior to the $\mathrm{pH}$ in $\mathrm{CaCl} 2$, demonstrating that on exchange complex, cationic-type reactions predominate over anionic ones. On the summit segment, represented by the Red Latosol with ferric characteristics (BHERING et al., 2007), the $\mathrm{pH}$ data in water were constant, presenting a predominantly neutral reaction (>6.6) on $\mathrm{Ap}, \mathrm{Bw} 1$, and $\mathrm{Bw} 2$ horizons, and it presented a moderate acidity (6.5) only on AB volume, according to Embrapa (2013) classification.

The sum of bases $(\mathrm{S})$ together with potential acidity $(\mathrm{H}+\mathrm{Al})$ indicate a relatively low cationic exchange capacity (CEC) on soil volumes of this toposequence, varying between 7.77 and 17.27 cmolc dm-3 meeting the chemical criteria established by Embrapa (2013) for Latosols and Nitosols.

Saturation by bases (V) (Table 2) presents values with an amplitude of up to $56 \%$ on the toposequence soil volumes. The higher values are concentrated in the pedological set of amount, that varied between $60.96 \%$ and $78.87 \%$. These values are reduced on the transition to the lower slop since a substantial part of B nitic and Bw shows less than $50 \%$ of saturation by bases.

According to the third categorical level of soil classification in Brazil (EMBRAPA, 2013), such soils are characterized as eutrophic on the summit and dystrophic from the medium slope 
sector to the foothill.

Thus, the classification points to eutroferric and/or distroferric soils, an indication that the toposequence of the Marechal Plateau presents an pedological system organized on the top sector that correspond to the Eutroferric Red Latosol soil horizons, and laterally, it switches to the latosolic Distroferric Red Nitosol soil horizons.

Table 2 - Chemical characteristics of Marechal Plateau soil profiles toposequence.

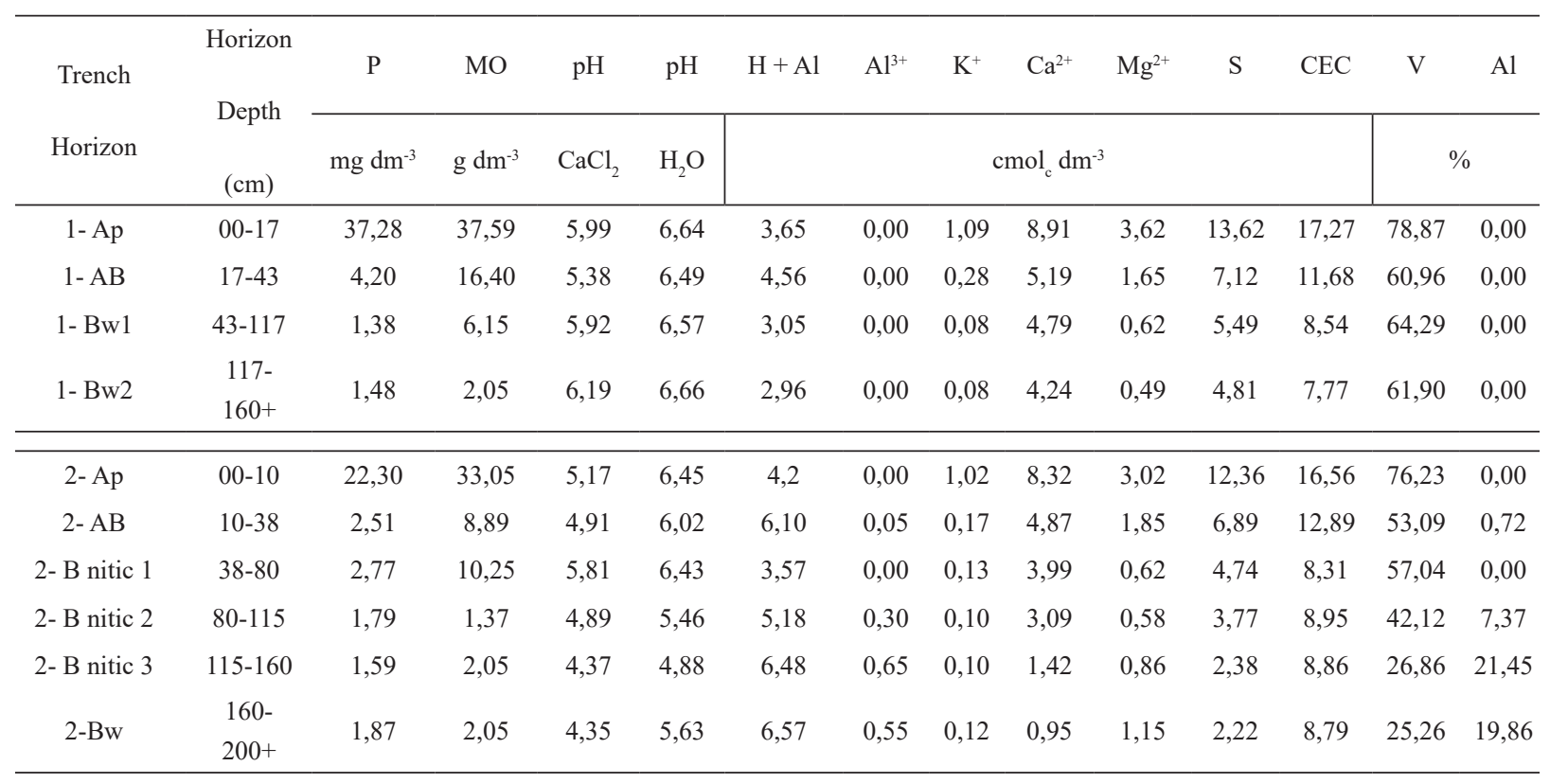

\section{MICROMORPHOLOGICAL ATTRIBUTES}

In order to maximize the presentation and generate subsidies for understanding the hydric dynamics of the slopes, all horizons of the Marechal Plateau pedological system are detailed. The Ap horizon (from both soils) presents itself with two different types of arrangements (coarse/fine-related distribution) in micromorphological terms; one of continuous porphyric fabric and the other of enaulic fabric. The porphyric zones that represent half the volume are surrounded by enaulic zones, in similar proportions (Table 3 and Figure 3-a).

The microaggregate that appear on enaulic fabric zones are essentially made of dark red soil material, ferruginous clay micromass, undifferentiated to speckled b-fabric, even under increased zoom and bright light, bordered by a narrow band of red-yellow, speckled micromass (Figure 3-a). They present different dimensions mainly between 0.5 and $2 \mathrm{~mm}$ in diameter, strong pedality, not accommodated with each other.

On porphyric fabric zones, the aggregates present subangular shapes with diameters higher than $3 \mathrm{~mm}$. Such continuous zones are the result of the rounded microaggregates cluster, coalesced with each other by the red-yellow micromass.

The difference on the arrangements imply variations on porosity type, on enaulic zones, inter-aggregated pores of high connectivity - compound packing voids predominate. There is still a finer intra-aggregate porosity as emphasized by some authors (COOPER; VIDAL-TORRADO, 2005), not observable on this analysis scale. On porphyric zones, porosity consist of two different types of pores: cavities and planar pores. The larger cavities are policoncave $(400 \mu \mathrm{m})$ and the smaller ones are oval shaped $(205 \mu \mathrm{m})$, occasionally more elongated and curved presenting weak or null connectivity. On the other hand, planar pores are thin and accommodated (15 to $40 \mu \mathrm{m}$ fissures), or wider and unaccommodated, dividing the larger continuous zones into smaller polyhedral aggrega- 
tes. The wider planar pores $(60 \mu \mathrm{m})$ are normally longer and interconnected with a close compound packing porosity. The thinner pores tend to be shorter and could be either interconnected or not with the general porous system. Some tubular voids filled by microaggregates were also observed, confirming biological activity.

Table 3 - Micromorphological description of the pedological system of soil horizons from Marechal Plateau.

\begin{tabular}{|c|c|c|c|c|c|c|}
\hline \multirow[b]{2}{*}{ Horizons } & \multicolumn{6}{|c|}{ Attributes } \\
\hline & General & Microstructure & Micromass & Coarse Material & Pores & Fabric \\
\hline Ap & $\begin{array}{l}\text { Heterogeneous. } \\
\text { Two types of ar- } \\
\text { rangements: } \\
1(50 \%) \text { e } 2(50 \%) \text {. }\end{array}$ & $\begin{array}{l}\text { 1) Rounded micro- } \\
\text { aggregates } \\
\text { 2) Subangular } \\
\text { blocky }\end{array}$ & $\begin{array}{l}1 \text { e 2) Ferruginous } \\
\text { clay, dark-red, } \\
\text { undifferentiated to } \\
\text { speckled b-fabric, } \\
\text { and yellow-red } \\
\text { speckled }\end{array}$ & $\begin{array}{l}1 \text { e 2) Few dark } \\
\text { minerals (ilmenite } \\
\text { and magnetite), } \\
\text { angular to suban- } \\
\text { gular }\end{array}$ & $\begin{array}{l}\text { 1) Inter-aggregates, } \\
\text { compound packing } \\
\text { voids } \\
\text { 2) Planes and } \\
\text { poly-concave and } \\
\text { oval vughs }\end{array}$ & $\begin{array}{l}\text { 1) Enaulic } \\
\text { 2) Porphyric } \\
\text { continuous }\end{array}$ \\
\hline $\mathbf{A B}$ & $\begin{array}{c}\text { Heterogeneous. } \\
\text { Three types of } \\
\text { arrangements: } \\
1(30 \%), 2(50 \%), 3 \\
(20 \%)\end{array}$ & $\begin{array}{c}\text { 1) } \\
\text { Coalesced roun- } \\
\text { dend microaggre- } \\
\text { gates2) Rounded } \\
\text { microaggregates } \\
\text { and subangular } \\
\text { blocky } \\
\text { 3) Rounded micro- } \\
\text { aggregates }\end{array}$ & $\begin{array}{l}\text { 1, } 2 \text { e 3) Ferrugi- } \\
\text { nous clay, dark-red, } \\
\text { undifferentiated } \\
\text { and yellow-red } \\
\text { speckled }\end{array}$ & $\begin{array}{l}\text { 1, } 2 \text { e 3) Few dark } \\
\text { minerals (ilmenite } \\
\text { and magnetite), } \\
\text { angular to suban- } \\
\text { gular }\end{array}$ & $\begin{array}{l}\text { 1) Elongated or } \\
\text { curved and poly-con- } \\
\text { cave vughs elonged } \\
\text { 2) Planes and oval } \\
\text { vughs } \\
\text { 3) Inter-aggregates, } \\
\text { compound packing } \\
\text { voids }\end{array}$ & $\begin{array}{l}\text { 1) Porphyric - } \\
\text { discontinuous } \\
\text { 2) Porphyric - } \\
\text { continuous } \\
\text { 3) Enaulic }\end{array}$ \\
\hline $\begin{array}{l}\text { Bw1/ } \\
\text { Bw2 }\end{array}$ & $\begin{array}{l}\text { Heterogeneous. } \\
\text { Three types of ar- } \\
\text { rangements: } \\
1(25 \%), 2(25 \%), 3 \\
(50 \%)\end{array}$ & $\begin{array}{l}\text { 1) Subangular } \\
\text { bloky } \\
\text { 2) Subangular } \\
\text { bloky } \\
\text { 3) Rounded micro- } \\
\text { aggregates }\end{array}$ & $\begin{array}{l}\text { 1, } 2 \text { e } 3 \text { ) Ferrugi- } \\
\text { nous clay, dark-red, } \\
\text { undifferentiated } \\
\text { and yellow-red } \\
\text { speckled }\end{array}$ & $\begin{array}{l}\text { 1, } 2 \text { e 3) Few dark } \\
\text { minerals (ilmenite } \\
\text { and magnetite), } \\
\text { angular to suban- } \\
\text { gular }\end{array}$ & $\begin{array}{l}\text { 1) Long and open } \\
\text { planes } \\
\text { 2) Oval vughs } \\
\text { 3) Compound pack- } \\
\text { ing voids }\end{array}$ & $\begin{array}{l}\text { 1) Porphyric - } \\
\text { continuous } \\
\text { 2) Porphyric - } \\
\text { discontinuous } \\
\text { 3) Enaulic }\end{array}$ \\
\hline B nitic & $\begin{array}{l}\text { Heterogeneous. } \\
\text { Three types of } \\
\text { arrangements: } 1 \\
(70 \%) \text { e } 2(10 \%) \text { e } \\
3(20 \%)\end{array}$ & $\begin{array}{l}\text { 1) Subangular } \\
\text { blocky } \\
\text { 2) Rounded micro- } \\
\text { aggregates } \\
\text { 3) Agregados } \\
\text { poliédricos suban- } \\
\text { gurales }\end{array}$ & $\begin{array}{l}\text { 1, } 2 \text { e } 3 \text { ) Ferrugi- } \\
\text { nous clay, dark-red, } \\
\text { mosaic-speckled } \\
\text { and micromass red } \\
\text { to yellow-red, stri- } \\
\text { ated b-fabric }\end{array}$ & $\begin{array}{l}\text { 1, } 2 \text { e 3) Few dark } \\
\text { minerals (ilmenite } \\
\text { and magnetite), } \\
\text { angular to suban- } \\
\text { gular }\end{array}$ & $\begin{array}{l}\text { 1) Planar and oval } \\
\text { vughs } \\
\text { 2) Compound pack- } \\
\text { ing voids } \\
\text { 3) Planar, and vughs }\end{array}$ & $\begin{array}{l}\text { 1Porphyric - } \\
\text { continuous } \\
\text { 2) Enaulic } \\
\text { 3) Porphyric - } \\
\text { continuous }\end{array}$ \\
\hline Bw & $\begin{array}{l}\text { Heterogeneous. } \\
\text { Three types of ar- } \\
\text { rangements: } \\
1(20 \%), 2(10 \%), 3 \\
(70 \%)\end{array}$ & $\begin{array}{l}\text { 1) Subangular } \\
\text { blocky } \\
\text { 2) Subangular } \\
\text { blocky } \\
\text { 3) Rounded micro- } \\
\text { aggregates }\end{array}$ & $\begin{array}{l}\text { 1, } 2 \text { e 3) Ferrugi- } \\
\text { nous clay, dark-red, } \\
\text { undifferentiated } \\
\text { and yellow-red } \\
\text { speckled }\end{array}$ & $\begin{array}{l}\text { 1, } 2 \text { e 3) Few dark } \\
\text { minerals (ilmenite } \\
\text { and magnetite), } \\
\text { angular to suban- } \\
\text { gular }\end{array}$ & $\begin{array}{l}\text { 1) Long and open } \\
\text { planes } \\
\text { 2) Oval vughs } \\
\text { 3) Compound pa- } \\
\text { cking voids }\end{array}$ & $\begin{array}{l}\text { 1) Porphyric - } \\
\text { continuous } \\
\text { 2) Porphyric - } \\
\text { discontinuous } \\
\text { 3) Enaulic - open }\end{array}$ \\
\hline
\end{tabular}

The AB sub superficial horizon (Figure 3-b) presents a dominant porphyric fabric encompassing small sectors of enaulic fabrics similar to those noted on the superior horizon. Porphyric zones are discontinuous and continuous at times. Similar to the superior horizon, these porphyrics are formed 
due to micro-aggregates grouping and the discontinuous or continuous porphyric variation reveals different agglutination stages: discontinuous porphyric - a stage where rounded volumes are noticeable with some vughs elongated and curved and others policoncave $150 \mu \mathrm{m}$ around it; continuous porphyric - a stage where original rounded shapes are already deformed, showing some small oval vughs ( 20 to $40 \mu \mathrm{m})$, aligned along welding plans resulting in a reticular distribution pattern.

On open enaulic and porphyric zones, micromass is dark-red, ferruginous clay, speckled, and undifferentiated, presenting on some sectors, aggregated or vughs edges, a clearer red-yellowish and speckled micromass. On continuous porphyric zones, the red-yellowish micromass appears striated on some sectors, in the contact bands between the originally rounded volumes of the microaggregates, now deformed and welded with each other. Corresponds to stress cutan in Brewer's classification (BREWER, 1976).

On the whole, the material is organized in aggregates of subangular polyhedral shape with around $1.000 \mu \mathrm{m}$ in diameter. On zones of discontinuous porphyric fabric, the microaggregates coalescence that started it caused the closing of porosity, originally interaggregated of compound packing voids, and the appearing of a mainly vugh porosity - policoncave pores $(25 \mu \mathrm{m})$ or elongated and curved - and planar, partially connected, presenting $40 \mu \mathrm{m}$ width at the most. Such coalescence condition and porosity alteration were also checked by Cooper and Vidal-Torrado (2005), in Bw horizon.

In continuous porphyry zones, planar pores appear more frequently, consisting of short, thin $(\sim 25 \mu \mathrm{m})$ and accomodated, partially connected, when intra-aggregated, and wider and unaccomodated $(45 \mu \mathrm{m})$ inter-aggregated cracks. Vugh pores are smaller, normally oval, and in small amounts. They can locally present a reticular distribution, as observed on Ap horizon. Some filling pedological features made of light yellow micromass in some pores can be noted.

The subjacent horizons of Latosol Bw1 and Bw2 are quite similar in physical, hydric, (Figure 3, Table 4), and micromorphological (Figure 3-c) terms. They show continuous porphyric fabric sectors cut by (long with 15 to $30 \mu \mathrm{m}$ opening) planes, separating subangular polyhedral peds moderately accommodated and discontinuous porphyric fabric sectors with vugh porosity, similar to the ones observed on the AB horizon. These zones appear involved by longer sectors made of rounded-shaped microaggregates agglomerates (100 to $200 \mu \mathrm{m}$ in diameter), non-accommodated, dominated by enaulic fabric described by Cooper (1999) in Bw horizon of a Eutroferric Nitosol. The prevalent micromass is dark-red undifferentiated to speckled, hemmed by narrow strips of speckled red-yellowish micromass.

As an example of what was noted on $\mathrm{AB}$ horizon, porphyric zones have reduced porosity made also by planar pores and policoncave and oval vughs. It is noted, however, an elevation on porosity due to the increase of enaulic fabric zones dominated by compound packing voids. Agglomeration of microaggregates often produces a reduction on porosity packing transforming it into policoncave vughs in certain places. Such condition was also verified by Silva and Castro (2015) when describing the Bw of a Red Latosol, prevalent of enaulic distribution, strong pedality (microaggregated) with small porphyric thickened zones in small sub rounded blocks. Indicating also, the prevalence of pilling inter-granular macroporosity, with channels, vughs, and/or millimeter chambers associated to the mesofauna, as well as filling features with material from the same horizon.

The micromorphological characteristics noted on summit soil (Latosol) for Ap and AB horizons remain along the entire toposequence, also appearing on $\mathrm{Ap}$ and $\mathrm{AB}$ horizons on trench 2 (Nitosol), on the low hillside.

$\mathrm{B}$ nitic horizon appears from the medium slope towards the foothill, right below AB horizon (Figure 2). As seen in Figure 3-d, such horizon presents a continuous porphyric fabric prevalent and some isolated enaulic fabrics sectors. The micromass is dark-red, mosaic speckled, appearing on the edges of the aggregates with lighter color - red to yellow-red. 

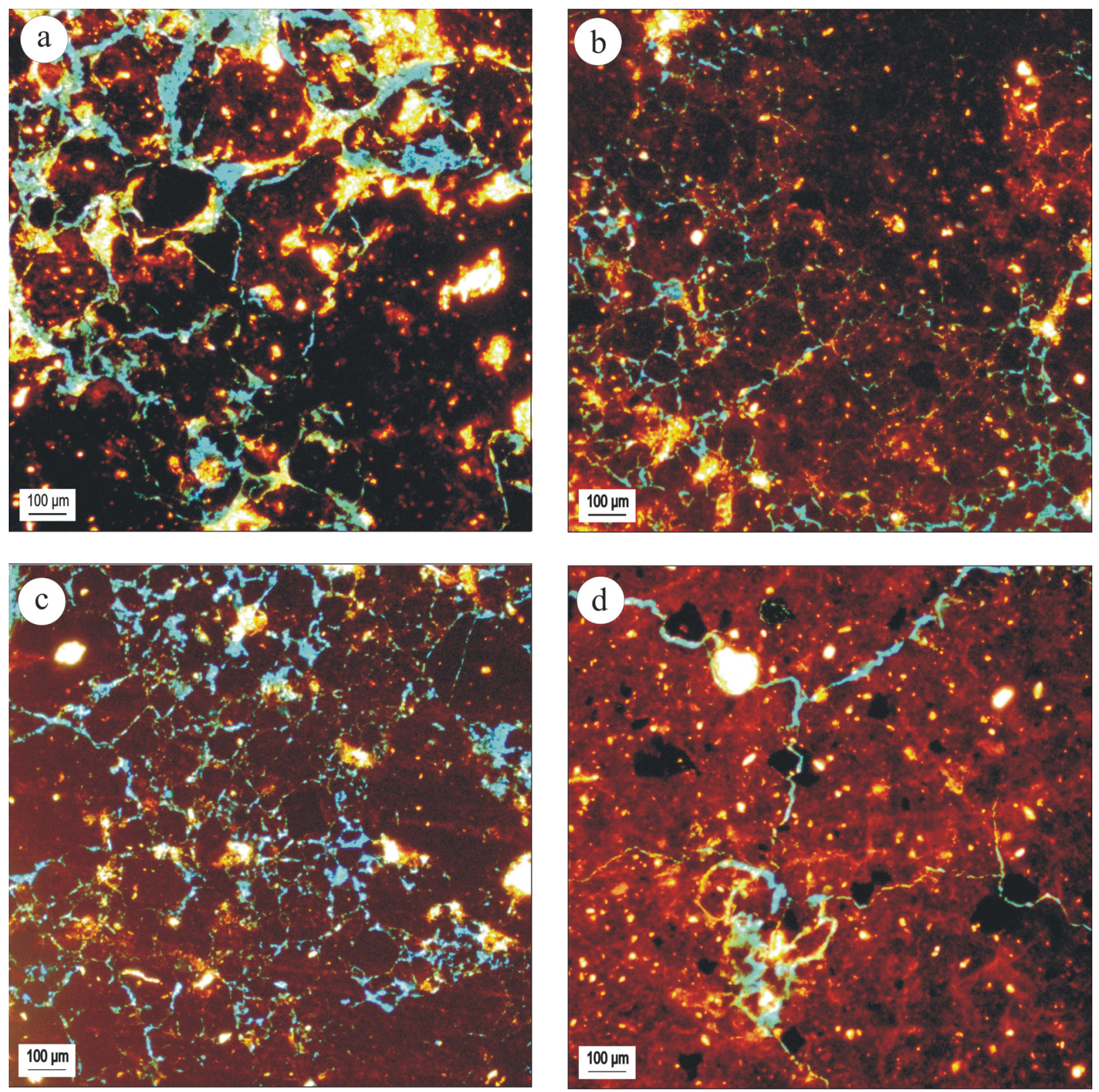

Figure 3 - Soil horizons photomicrographs from the Marechal Plateau toposequence. a) Ap volume - Transition from discontinuous porphyric fabric and enaulic fabric zone with compound packing voids. b) AB volume - Redyellowish micromass with "stress cutans" and highlight to coalescence of microaggregates. c) Bw volume Porphyric fabric and agglomerates of microaggregates. d) Nitic volume - Porphyric fabric, subangular polyhedral aggregates, and inter-aggregated planar dominant porosity.

The structure is composed by subangular polyhedral aggregates varying from 1 to $4 \mathrm{~mm}$, partially to totally accommodated, and blocks smaller than $500 \mu \mathrm{m}$. The prevalent porosity is connecting inter-aggregated planar, with openings of 10 to 30 micrometers.

Oval-shaped vugh porosity is prevalent inside the aggregates $(\sim 40 \mu \mathrm{m})$ and non-connected thin fissures. Oval section channels appear on some larger polyhedral blocks, filled by very small aggregates (160 and $300 \mu \mathrm{m})$, resulting from the biological activity.

On the field, B nitic horizon was subdivided into three volumes due to small morphological differences, confirmed by physical data (Tables 1 and 4). The B nitic summit is denser, whereas its center and base are less dense. That is micro morphologically represented by the increase of discontinuous porphyric fabric sectors in relation to the continuous porphyric fabric ones and by variations on the porous system, with the increase of vughs in relation to planar pores in the center and on the horizon's base. 
Effects of biological activity evidenced by the presence of channels and pedofeatures of loose filling (microaggregates), more often on the central portion of B nitic horizon, are also responsible for physical variations noted on its interior (soil density and porosity).

This structure of aggregates in polyhedral and granular blocks is prevalent to up to $160 \mathrm{~cm}$ of depth on the toposequence; Bw appears again, in this slope segment below B nitic, with characteristics similar to the ones observed on the summit, yet with more discontinuous enaulic fabric sectors as indicated by the soil density data, significantly lower.

The coarse material (macromass) appears in small quantities along the entire pedological cover and on all horizons as confirmed by the granulometric data (Table 1). They are dark mineral grains (ilmenite and magnetite), normally angular to subangular, disperse and involved my thin material (micromass). Such material is seen in Figure 3-d.

\section{HYDRIC ATTRIBUTES}

The vertical and lateral variation of soil density data on Marechal Plateau (Table 4), evince a greater densification on superior horizons of the cover, more significant on AB horizon, followed by a reduction in porosity. It presents total porosity decreased by around $10 \%$ in relation to the superficial horizon on summit position, and by around $15 \%$ on the slope foothill. However, macroporosity is mainly affected by that decrease, which varies between $56 \%$ (summit) and $66 \%$ (foothill).

Table 4 - Porosity, soil density and hydraulic conductivity of soil profiles from Marechal Plateau toposequence.

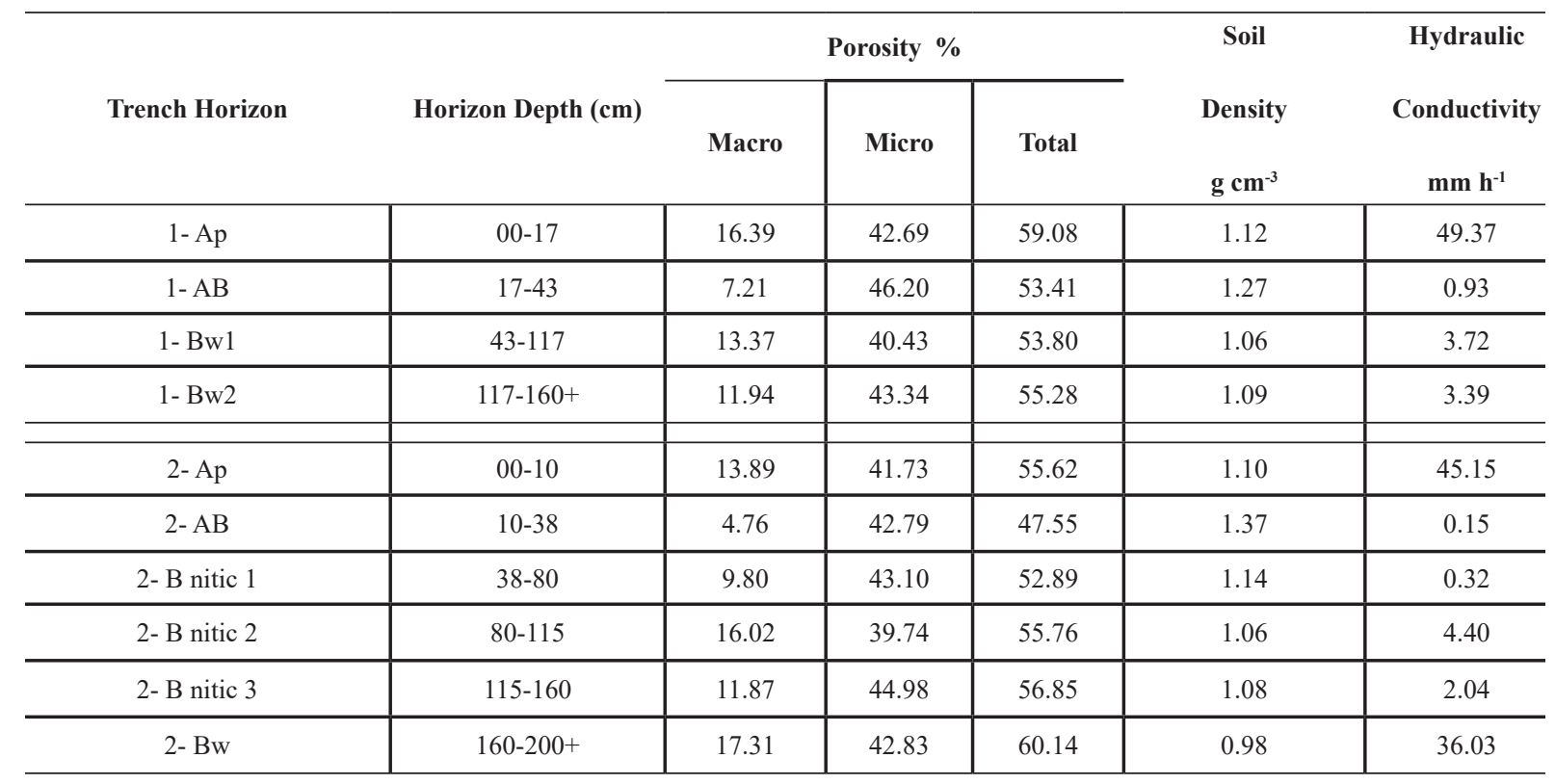

On subjacent horizons, soil density decreased sharply on transitions to $\mathrm{Bw}$ and $\mathrm{B}$ nitic. The values are close, be it on $\mathrm{Bw}(\mathrm{Bw} 1$ and $\mathrm{Bw}$ ) from the high sector of the slope or be it on $\mathrm{B}$ nitic (B1 nitic, B2 nitic, B3 nitic). Nevertheless, Bw, on the low slope, presents the lowest soil density values of the entire toposequence (Figure 4).

That behavior is also reflected in the total porosity data, which is similar on Bw and B nitic. Using $\mathrm{AB}$ horizon as a reference, it can be noted, however, that the total porosity values on the upward sector of the toposequence have a slight increase in depth (3.5\%) on Bw2. This increase is more significant on the low slope (around 11\%) for B1 nitic, right below $\mathrm{AB}$, gradually increasing, reaching $26.5 \%$ on $\mathrm{Bw}$, below $\mathrm{B} 3$ nitic. The substantially reduced macroporosity on $\mathrm{AB}$ horizon increases on $\mathrm{B}$ horizons ( $\mathrm{Bw}$ and $\mathrm{B}$ nitic), more than $85 \%$ on summit $\mathrm{Bw} 1$ and $105 \%$ on $\mathrm{B} 1$ nitic on the low slope sector. While macroporosity is generated by structural arrangements of soil materials, microporosity is restricted by the texture of the material. Macroporosity allows free hydric 
circulation and microporosity acts mainly on water retention and its storage. Thus, as the structure is transformed, the balance between macro and microporosity changes, as noted along this toposequence, both vertically and laterally, hence able to produce hydrological behavior variations of the pedological cover.

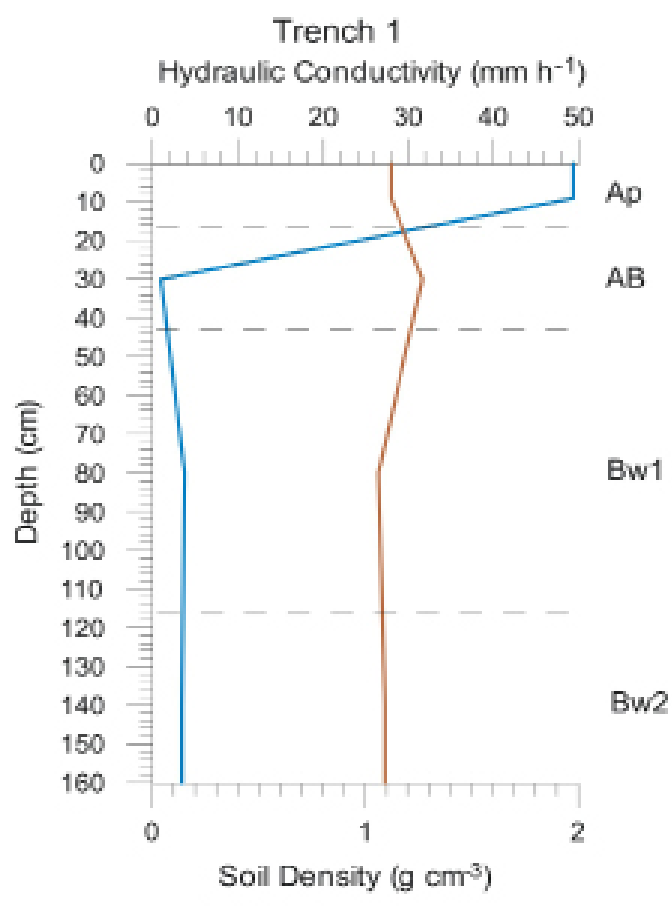

Hydraulic Conductivity

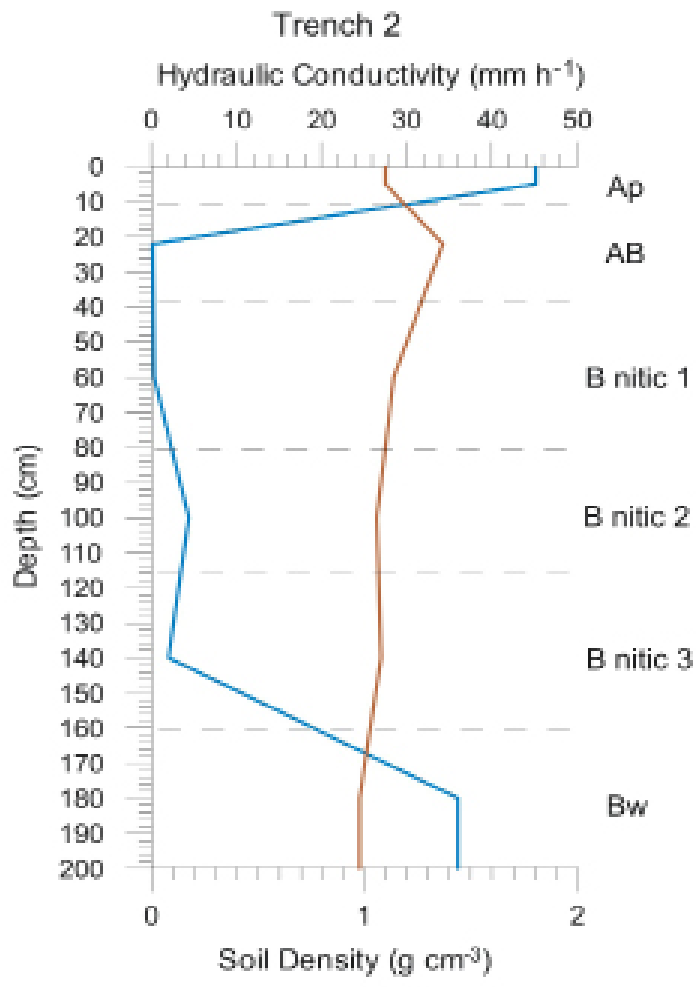

Soil Density

Figure 4 - Hydraulic conductivity and soil density correlation of Marechal Plateau toposequence.

As shown by the data (Table 4), microporosity prevails on this pedological cover, representing $72 \%$ to $79 \%$ of poral system on the toposequence summit, showing that it reaches $86 \%$ on $\mathrm{AB}$ horizon due to densification and on its foothill there are variations between $71 \%$ and $82 \%$, reaching $90 \%$ on $\mathrm{AB}$ horizon. Textural porosity is prevalent, favoring water retention. The data from hydraulic conductivity tests (Table 3 and Figure 5) confirm a correlation between porosity (macro and microporosity) and the hydric behavior of the pedological cover.

In hydric terms, Ap superficial horizon along the entire toposequence presents moderate hydraulic conductivity ( $49.37 \mathrm{~mm} \mathrm{~h}-1$ upstream and $45.15 \mathrm{~mm} \mathrm{~h}-1$ downstream) favoured by greater porosity; very slow on $\mathrm{AB}$ horizon (values below $1.00 \mathrm{~mm}$ h-1 with greater reduction on low slope); slow on Bw volumes on summit (3.72 mm h-1 for Bw1 and $3.39 \mathrm{~mm} \mathrm{~h}-1$ for Bw2). From the medium slope, it turns laterally very slow on B nitic summit $(0.32 \mathrm{~mm} \mathrm{~h}-1$ on B1 nitic), remaining slow on B2 nitic (4.40 mm h-1) and B3 nitic (2.07 mm h-1). Hydraulic conductivity only increases from the medium slope on Bw, subjacent to B nitic, still moderate (36.03 mm h-1). 


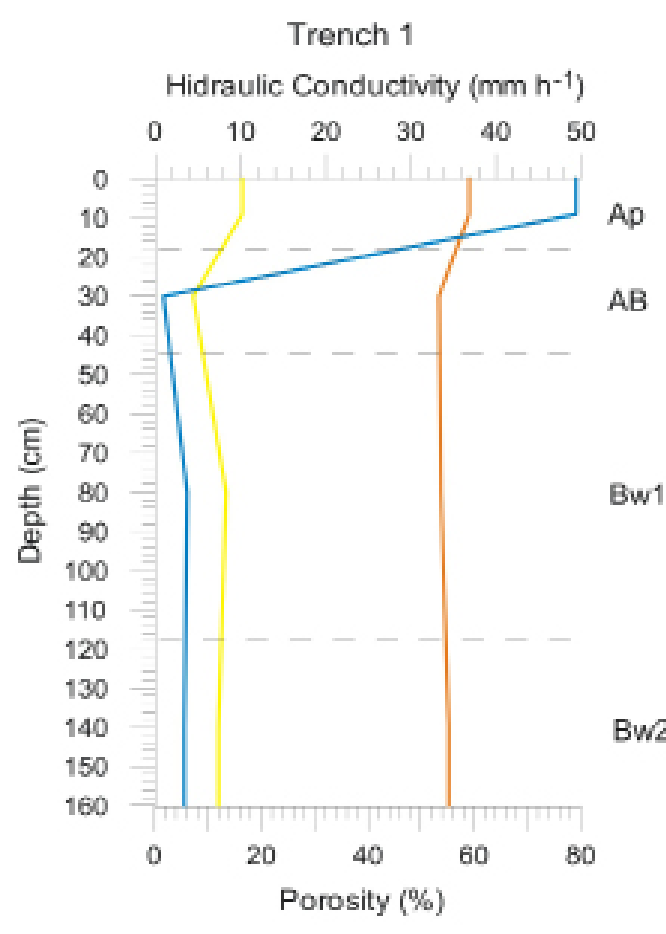

Macro

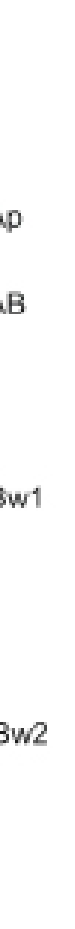

Micro
Trench 2

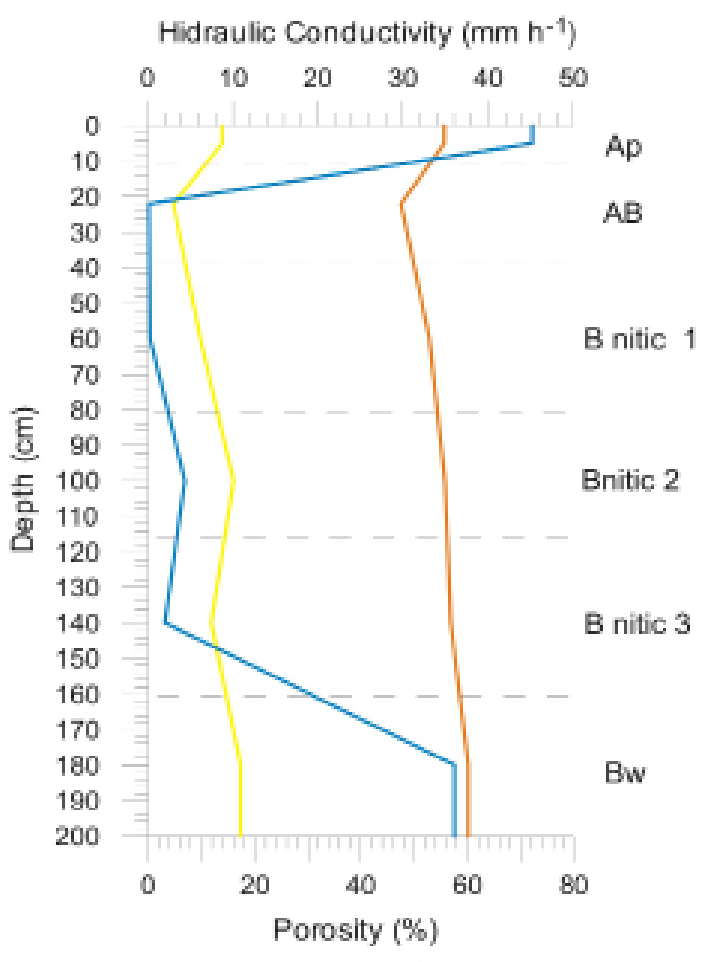

Hidraulic Conductivity

Figure 5 - Hydraulic conductivity correlation with macro and microporosity of soils from Marechal Plateau toposequence.

Despite a hydraulic conductivity growth trend with the increase of total porosity and macroporosity, as seen on data, total porosity or macroporosity increase is not followed by hydraulic conductivity with the same intensity. More elevated total porosity and macroporosity on Bw were not able to restrict the same hydraulic conductivity rates as on Ap horizon, likewise, similar porosity values, or more specifically, macroporosity ones do not correspond to rates close to hydraulic conductivity.

Similar behavior can be noted when correlating soil density data with hydraulic conductivity (Figure 4). The close relation between total porosity and soil density does not extend to hydraulic conductivity.

The study from Tavares-Filho et al. (2006) corroborates with this discussion, where the hydraulic conductivity achieved with infiltrometer at $15 \mathrm{~cm}$ in depth in a dystrophic Red Latosol in the North of Paraná state, Brazil, under direct planting after 20 years, generated an average of $2.1510-5 \mathrm{~m}$ $\mathrm{s}-1$ (77 mm h-1), that is to say, a moderately fast hydraulic conductivity. Those authors concluded that nonsoil inversion in conjunction with agricultural machinery traffic has caused an increase in soil density in Ferralsols and Nitosols from the North of Paraná state, reaching values close to 1.50 g cm-3 and they could decrease significantly after scarification, reaching values of $0.99 \mathrm{~g} \mathrm{~cm}-3$.

For the Marechal Plateau soils, balance interferences between macro and microporosity on the hydric behavior of this pedological cover must be considered as well as pore types, their degree of connectivity, and distribution, especially with regards to macroporosity, the general agent for hydric circulation. The micromorphological observations contribute to understanding the poral system configuration and its operation.

Figure 6 shows type, distribution, and size variations of pores observed on thin sections of soil volumes typical of this toposequence. As indicated by the micromorphological analysis, a porous system transformation occurs from the surface to the base of the studied soils, seen along the entire toposequence, with some lateral differences related to $\mathrm{Bw}$ transformation into $\mathrm{B}$ nitic, from summit to the slope foothill. 
Vertically, it can be noted that the superficial volume (Ap horizon) of the pedological cover shows a significant porosity part (macroporosity) of compound packing voids type, generated by the enaulic arrangement of approximately half the horizon's groundmass. On continuous arrangement zones (porphyric fabric), porosity is very small and of vugh and fissural type. The ratio between the two types of arrangements and their distribution ensure pores connectivity, mainly for the compound packing ones. However, below the superficial horizon, as seen in Figure 5, the material is dense (AB horizon), the enaulic zones are drastically reduced, the arrangement type is predominantly porphyric and the macroporosity is preferably of vugh and planes types with weak or null connectivity. Such poral space transformation implies the closing of a substantial part of structural porosity where the free hydric flows circulate and the microporosity responsible for water retention - textural porosity - increases. Hydraulic conductivity rates obtained (Table 3) confirm hydric behavior alteration.

Silva and Castro (2015) draw attention to the porphyric structure prevalence on $A$ and $A B$ superficial horizons, caused by heavy surface compaction in areas affected by crops changes, from grazing and soybean to sugarcane.

Similarly, Kertzman (1996) using binary images to represent the organization of microaggregates and their poral space, noted that from 10 to $35 \mathrm{~cm}$ depth on area cultivated with direct planting, soil porosity is much more reduced than woods-covered soils. Such compaction reduces water infiltration rates by over 20 times. For the author, such infiltration decrease was caused by the reduction of inter-aggregated pores and mainly by low connectivity.

Despite the increase of macroporosity and total porosity on Bw horizon (Bw1 and $\mathrm{Bw} 2)$ on the superior slope stretch and on B (B1 nitic, B2 nitic, B3 nitic), the low hydraulic conductivity values confirm the weak connectivity of porosity. Even with the increase of enaulic fabric zones and compound packing porosity in relation to porphyric zones on Bw1 and Bw. Upstream, the tendency to the agglomeration of such microaggregates transforms a significant part of compound packing porosity in vugh porosity, decreasing its connectivity, hence the reduced hydraulic conductivity rates. Downstream, the predominantly fissural and vugh porosity typical of B nitic is responsible for low conductivity. The subjacent Bw horizon, on medium and low slope, presents inter-aggregated porosity zones (compound packing voids) more enlarged and inter-connected, containing porphyric zones with lightly connected vugh porosity, but causing less interference on hydric circulation, making moderate hydric circulation similar to the one observed on the Ap superficial horizon possible, as per the obtained values. 


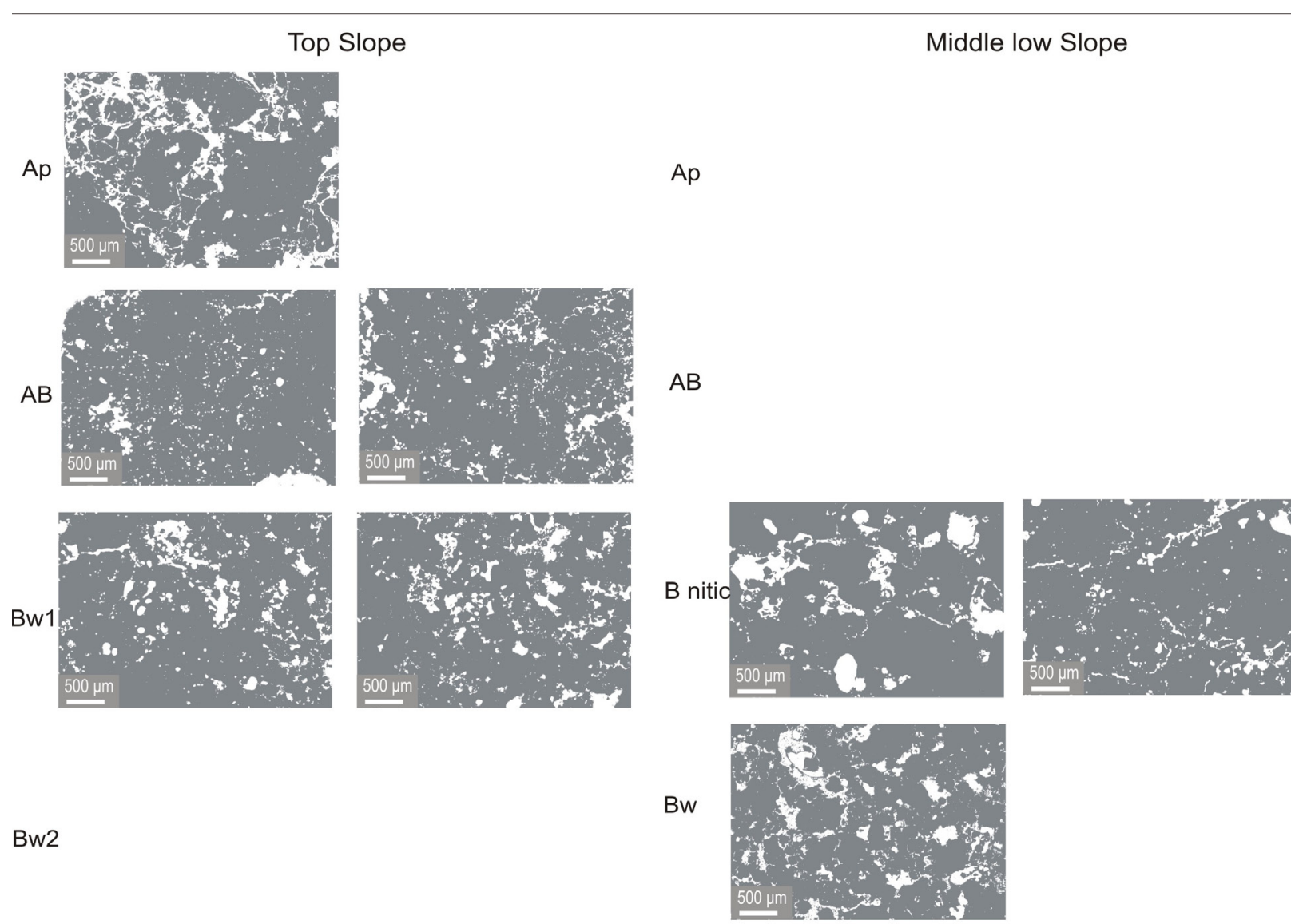

Figure 6 - Binary images of soils horizons porous systems from Marechal Plateau. Poroids are shown in white and solid phase in gray.

The micromorphological analysis confirms that pore type, its organization, and distribution on the soil groundmass condition porosity connectivity and, consequently, hydraulic conductivity, justifying also the variations and relations between this analysis and the total porosity, macro, and microporosity data seen on the horizons.

\section{FINAL CONSIDERATIONS}

On the pedological system, made of Eutroferric Red Latosol and latosolic Distroferric Red Nitosol, the soils present a high degree of evolution confirmed by the low silt/clay relation rates, however, the diagnostic $\mathrm{Bw}$ and $\mathrm{B}$ nitic horizons do not present $100 \%$ clay-fraction flocculation.

In micromorphological terms, the pedological system presents particular structural characteristics for each horizon, sometimes repeated on the others. On the Ap horizon, the microstructure of rounded, subrounded, and granular aggregates under prevalent enaulic fabrics is well-noticed. On the AB horizon, the porphyric fabrics are formed by the grouping of microaggregates and vary from discontinuous to continuous porphyric fabric, according to different agglutination stages. Notoriously, the coalescence of these microaggregates imply the closing of the porous system, originating vugh pores (policoncave or elongated and curved), and planes, partially connected.

On latosolic B horizon, the enaulic fabric characteristics - rounded and subrounded microaggregates (crumb microstructure) and compound packing voids - is only common on deeper Bw. Porphyric fabric sectors cut by planes are frequent, distinguishing moderately accommodated subangular polyhedral blocks, discontinuous porphyric fabric sectors with vugh porosity, similar to the ones observed on $\mathrm{AB}$ horizon, and more extensive sectors made of round-shaped, non-accommodating microaggregates agglomerations ruled by enaulic fabric. 
B nitic horizon presented a prevalent discontinuous porphyric fabric and its structure is composed of subangular polyhedral aggregates, partially to totally accommodated, with some isolated enaulic fabric sectors. It is worth mentioning that field and micromorphological observations on $\mathrm{Bw}$, below B nitic, infer a possible transformation of this horizon into polyhedral structures, taking $\mathrm{B}$ nitic characteristics.

In hydric terms, despite the tendency for hydraulic conductivity growth with the increase of both total porosity and macroporosity as shown by data, it is noted that total porosity and macroporosity increase is not followed by hydraulic conductivity with the same intensity. The highest total porosity and macroporosity on $\mathrm{Bw}$ were not capable of conditioning the same hydraulic conductivity rates as seen on Ap horizon. Likewise, similar macroporosity values do not correspond to rates close to hydraulic conductivity.

The same behavior can be noted when comparing soil density data and hydraulic conductivity. The close relation between total porosity and soil density does not extend to hydraulic conductivity. The micromorphological observation contributed to the understanding of the porous system and its operation. Then, balance interferences between macro and microporosity on this pedological cover's hydric behavior must be considered in the same way as pores types, their distribution, and degree of connectivity, mainly regarding macroporosity, as it is the general agent for hydric circulation.

\section{BIBLIOGRAPHICAL REFERENCE}

BARBOSA, G. M. C.; OLIVEIRA, J. F.; MIYAZAWA, M.; RUIZ, D. B.; TAVARES FILHO J. Aggregation and clay dispersion of an oxisol treated with swine and poultry manures. Soil \& Tillage Research, n. 146, p. 279-285, 2015. Disponível em: <https://www.researchgate.net/publication/268691349>. Acesso em: 10 mar. 2016.

BERTONI, J.; LOMBARDI NETO, F. Conservação do solo. $5^{\text {a }}$ ed. São Paulo: Icone, 2005.

BHERING, S. B.; SANTOS, H. G.; MANZATTO, C. V.; BOGNOLA, I.; FASOLO, P. J; CARVALHO, A. P.; POTTER, O.; AGLIO, M. L. D.; SILVA, J. S.; CHAFFIN, C. E.; CARVALHO JUNIOR, W. Mapa de solos do Estado do Paraná: escala 1:250.000. Rio de Janeiro: Embrapa Solos, 2007. Disponível em: $<$ https://www.embrapa.br/busca-de-publicacoes/-/publicacao/339505/mapa-de-solos-do-estado-do-parana>. Acesso em: 09 mar. 2016.

BREWER R. Fabric and mineral analysis of soils. $2^{\mathrm{a}}$. ed. New York: Krieger RE, 1976.

BULLOCK, P.; FEDOROFF, N.; JONGERIUS, A.; STOOPS, G.; TURSINA, T. Handbook for soil thin section description. Wolverhampton: Waine Research Publishers, 1985.

CARDOSO, E. G.; ZOTARELLI, L.; PICCININ, J. L.; TORRES, E.; SARAIVA, O. F.; GUIMARÃES, M.F. Sistema radicular da soja em função da compactação do solo no sistema plantio direto. Pesquisa Agropecuária Brasileira, n. 41, p. 493-501, 2006.

CASTRO, S. S. de. Sistema de transformação pedológica em Marília: B latossólico em B textural. 1989. 274f. Tese (Doutorado em Geografia) - FFLCH - Depto. de Geografia. Universidade de São Paulo, 1989.

CASTRO, S. S.; COOPER, M.; SANTOS, M. C.; VIDAL TORRADO, P. Micromorfologia do solo. Tópicos de Ciências do Solo. Viçosa, MG: Sociedade Brasileira de Ciência do Solo, n. 3, p.107-164, 2003.

COOPER, M. Influência das condições físico-hídricas nas transformações estruturais entre horizontes B latossólico e B textural sobre diabásio. 1999. 135f. Tese (Doutorado em Agronomia) - ESALQ/USP Piracicaba - SP, 1999.

COOPER, M.; VIDAL-TORRADO, P. Caracterização morfológica, micromorfológica e físico-hídrica de solos com horizonte B nítico. Revista Brasileira de Ciência do Solo, n. 29, p. 581-595, 2005.

CUNHA, J. E.; NÓBREGA, M. T.; CASTRO, S. S. Infiltração da água no solo no sistema pedológico Campus do Arenito, cidade gaúcha, noroeste do estado do Paraná. Revista Brasileira de Ciência do Solo, n. 32, p. 1837-1848, 2008.

DE MARIA, I. C.; CASTRO, O. M.; SOUZA DIAS, H. Atributos físicos do solo e crescimento radicular 
de soja em Latossolo Roxo sob diferentes métodos de preparo do solo. Revista Brasileira de Ciência do Solo, n. 23, p. 703-709, 1999.

DERPSCH, R.; ROTH, C. H.; SIDIRAS, N. KOPKE, U. Controle da erosão no Paraná, Brasil: Sistemas de cobertura do solo, plantio direto e preparo conservacionista do solo. Londrina: IAPAR, 1991.

EMBRAPA (Empresa Brasileira de Pesquisa Agropecuária). Levantamento de reconhecimento de solos do Estado do Paraná. Curitiba: EMBRAPA - SNLCS / SUDESUL / IAPAR, 1984.

EMBRAPA (Empresa Brasileira de Pesquisa Agropecuária). Manual de métodos de análise de solo. Rio de Janeiro: CNPS, 1997.

EMBRAPA (Empresa Brasileira de Pesquisa Agropecuária). Sistema brasileiro de classificação de solos. $3^{\mathrm{a}}$ ed. rev. ampl. Brasília, DF: Centro Nacional de Pesquisa de Solos/Serviço de Produção e Informação, 2013. FILIZOLA, H. F., GOMES, M. A. F. Introdução à descrição micromorfológica de lâminas delgadas de solos. Comunicado Técnico. Jaguariúna: Embrapa, 2006. Disponível em: <http://www.cnpma.embrapa.br/ download/comunicado_41.pdf>. Acesso em: 10 mar. 2016.

KERTZMAN, F. F. Modificações na estrutura e no comportamento de um latossolo roxo provocadas pela compactação do solo. 1996. 153f. Tese (Doutorado em Geografia) - FFLCH - Departamento de Geografia. Universidade de São Paulo, 1996.

KIEHL, J. E. Manual de Edafologia. São Paulo: Agronômica Ceres, 1979.

MESQUITA, M. G. B. de F.; MORAES, S. O. A dependência entre a condutividade hidráulica saturada e atributos físicos do solo. Ciência Rural, Santa Maria, v.34, n.3, p.963-969, mai-jun, 2004. Disponível em: $<\mathrm{http} / / /$ www.scielo.br/pdf/cr/v34n3/a52v34n3.pdf $>$. Acesso em: 10 mar. 2016.

MINEROPAR (Minerais do Paraná S.A) - Atlas Geomorfológico do Estado do Paraná. Escala base 1:250.000. Curitiba: MINEROPAR, 2006. Disponível em <http://www.mineropar.pr.gov.br/>. Acesso em: 08 fev. 2016.

MAGALHÃES, V. L.; CUNHA, J. E.; NÓBREGA, M. T. Análise do sistema poroso e hídrico de uma vertente constituída por 'Latossolo-Nitossolo'. Revista Perspectiva Geográfica, Marechal Cândido Rondon, v. 10, n. 12, p. 43-62, 2015. Disponível em: <http://e-revista.unioeste.br/index.php/pgeografica/article/ view/14135/9632 >. Acesso em: 08 fev. 2016.

MORESCO, M. D. Estudo de paisagem no município de Marechal Cândido Rondon-PR. 2007. 137f. Dissertação (Mestrado em Geografia) - DGE/PGE/UEM. Maringá- PR, 2007.

NÓBREGA, M. T.; CUNHA, J. E. A paisagem, os solos e a suscetibilidade à erosão. Revista Espaço Plural, Marechal Cândido Rondon, v. 12, n. 25, p. 62-73, 2011. Disponível em: <http://e-revista.unioeste.br/index. php/espacoplural>. Acesso em: 08 fev. 2016.

PAVAN, M. A. ; BLOCH, M. F.; ZEMPULSKI, H. D.; MIYAZAWA, M.; ZOCOLER, D. C. Manual de análise química do solo e controle de qualidade. Londrina: IAPAR, 1992.

RAPER, R. L. Agricultural traffic impacts on soil. Journal of Terramechanics, n. 42, p. 259-280, 2005. Disponível em: < http://www.ars.usda.gov/SP2UserFiles/Place/60100500/csr/ResearchPubs/raper/raper_05g. pdf $>$ Acesso em: 10 mar. 2016.

REICHARDT, K. A água em sistemas agrícolas. São Paulo: Monole Ltda, 1990.

RUELLAN A.; DOSSO, M. Regards sur le sol. Paris: Les Éditions Foucher, 1993.

RUELLAN, A. Pedologia e desenvolvimento. In: CONGRESSO BRASILEIRO DE CIÊNCIA DO SOLO, 21, 1988, Campinas. A responsabilidade social da ciência do solo. Anais... Campinas: SBCS, 1988, p. 39-74. SANTOS, R. D. dos; SANTOS, H. G. dos; KER, J. C.; ANJOS, L. H. C. dos; SHIMIZU, S. H. Manual de descrição e coleta de solo no campo. Viçosa: SBCS, 2015.

SILVA, A. A.; CASTRO, S. S. Indicadores macro e micromorfológicos da qualidade física de um Latossolo Vermelho cultivado com cana-de-açúcar. Mercator, Fortaleza, v. 14, n. 3, p. 169-185, set./dez. 2015. Disponível em: $<$ http://www.mercator.ufc.br/index.php/mercator/article/view/1231/594>. Acesso em: 10 mar. 2016. TAVARES-FILHO, J.; FONSECA, I. C. de B.; RIBON, A. A.; BARBOSA, G. M. de C. Efeito da escarificação na condutividade hidráulica saturada de um Latossolo Vermelho sob plantio direto. Ciência Rural. v. 36, n. 3, p. 996-999, Santa Maria, mai/jun. 2006. Disponível em: 
$<$ http://www.scielo.br/scielo.php?\%20script=sci_arttext\&pid=S0103-84782006000300045>. Acesso em: 10 mar. 2016.

TAVARES FILHO, J., TESSIER, D. Effects of different management systems on porosity of oxisols in Paraná, Brazil. Revista Brasileira de Ciência do Solo, n. 34, p. 899-906, 2010.

VIDAL-TORRADO, P., LEPSCH, I. F., CASTRO, S. S. Conceitos e aplicações das relações Pedologia-Geomorfologia em regiões tropicais úmidas. In: VIDAL-TORRADO, P., ALLEONI, L. R. F., COOPER, M., SILVA, A. P., CARDOSO, E. J. (editores). Tópicos em Ciência do Solo. Viçosa, MG: Sociedade Brasileira de Ciência do Solo, 2005. v. 4, p. 145-192. 